\title{
The Electoral Success of the Extreme Right: Is the Presence of a Minority Important?*
}

\author{
MILOSLAV BAHNA and JOZEF ZAGRAPAN** \\ Institute for Sociology, Slovak Academy of Sciences
}

\begin{abstract}
Anti-minority rhetoric as an almost universal feature of extremeright parties is often analytically and empirically linked to their electoral success. This article tests the link between the presence of an outgroup and the vote for the extreme right in an attempt to explain the electoral success of the first openly anti-system extreme-right party to enter the Slovak parliament in 2016. A multilevel approach is used to analyse the connection between Roma presence in a municipality and extreme-right support while controlling for the individual characteristics of voters. Analysis using exit-poll data covering 161 municipalities and 20128 voters reveals no relationship between the presence of Roma in a municipality and support for the extreme right. A partial exception seems to be observed for older voters and the university-educated, who are generally the least inclined to far-right support. Interaction effects suggest that, for these groups, Roma presence might be connected to a higher probability to cast a vote for the extreme right. However, a notably higher chance of voting for the extreme right was associated with young, male, manual labourers and people without university education.
\end{abstract}

Keywords: extreme-right, Slovakia, election, Roma, group-threat

Sociologický časopis/Czech Sociological Review, 2020, Vol. 56, No. 3: 291-313

https://doi.org/10.13060/csr.2020.019

\section{Introduction}

The unexpected electoral success of the extreme right in the March 2016 parliamentary elections marks a new era in Slovak political discourse. Slovakia uses party-list proportional representation with one nationwide constituency to elect its members of parliament. Parties must win more than five per cent of the national vote to gain parliamentary representation. Even though the far-right People's Party-Our Slovakia (Ludová strana-Naše Slovensko / the L'SNS) has never polled over this barrier, it was able to receive more than eight per cent on the day

\footnotetext{
* Funding: This work was supported by the Slovak Research and Development Agency under Grants APVV-18-0218 and APVV-14-0527.

** Direct all correspondence to: Miloslav Bahna, Institute for Sociology, Slovak Academy of Sciences, e-mail: miloslav.bahna@savba.sk; Jozef Zagrapan, Institute for Sociology, Slovak Academy of Sciences, e-mail: jozef.zagrapan@savba.sk.
} 
of the 2016 election. Support for a party that uses a badly disguised racist discourse and promises, among other things, to fight 'parasites' from the (Roma) settlements was seen as the ultimate desperate choice of voters feeling threatened by Roma communities in the post-electoral media discourse. This explanation was also supported by previous research on electoral support for the extreme-right LSNS (which, until 2016, was marginal and obscure) in the 2012 parliamentary and 2013 local elections [Mikuš and Gurňák 2012; Spáč and Voda 2014].

In this study, we ask if the presence of Roma in a municipality can be identified as one of the driving forces of the 2016 electoral success of the extreme right. We do so by exploring the individual characteristics of voters combined with factors characterising their place of residence. We first discuss theoretical expectations and empirical findings regarding far-right party support and provide a brief introduction to the extreme right in Slovakia. Later, we introduce our methodological approach and present our findings. The concluding section summarises our main findings, the most important being that, contrary to previous studies, we do not find a clear link between voting for the extreme right and the presence of this marginalised minority in Slovakia. We also propose avenues for future research.

\section{Minority presence as an explanation of far-right support}

The Roma population in Central and Eastern Europe can in many regards serve as a typical example of an outgroup. Although present in these countries for centuries, the boundaries between the majority and the Roma are in most cases unambiguous. Roma people represent the outsider who is excluded from society. Fontanella, Villano and Di Donato [2015] suggest that this happens especially in the case of those with greater national identity and those who are more likely to show a larger prejudicial predisposition towards Roma people and also migrants. They add that Roma are 'the most discriminated even with respect to migrants' [Fontanella, Villano and Di Donato 2015: 17]. Data from the European Values Study (EVS) show that Slovak Roma are one of the least accepted minorities. For example, in the 2008 wave of the EVS, $47.1 \%$ of all respondents claimed that they would not like Roma as neighbours (compared to $16.6 \%$ of people who did not want immigrant worker neighbours and 22.3\% who did not want Muslim neighbours) [EVS 2011].

It can therefore be assumed that similar predictions apply to the relationship between a vote for the extreme right and the presence of Roma in Slovakia and the presence of outgroups, typically represented by immigrants, in Western Europe. The literature suggests that the presence of a minority is often linked to a feeling of threat. Blumer's group threat theory [1958] states that if the majority population feels threatened by an outgroup, it is likely to develop prejudice towards this outgroup, independent of whether the source of this threat is real 
or only perceived. He identifies four feelings and beliefs that might cause this behaviour: (1) a feeling of superiority over others; (2) a feeling of alienation from others and differences between these two groups; (3) a feeling of entitlement and ownership over certain rights and resources; (4) a feeling of fear that others will seek to claim a share of these privileges. Quillian [1995] mentions two circumstances that can potentially trigger a group threat feeling: the size of the minority group and bad economic conditions.

The expectation regarding the first factor is that, with the growth of the minority, the intensity of competition over scarce resources increases together with the potential of the minority to mobilise politically [Blalock 1967]. Previous research suggests that the prejudice of the majority is positively connected to the size of the outgroups [Quillian 1995] resulting in growing support for far-right parties. This conclusion is supported by cross-national studies [Golder 2003; Lubbers, Gijsberts and Scheepers 2002], but similar results were also found at the municipal level. There is solid research evidence, from Belgium, Britain, the Netherlands, and Austria, for example, confirming that the vote for the far right (whether it was Vlaams Blok, the British National Party, List Pim Fortuyn, or the Freedom Party of Austria) increased with the share of immigrants in a municipality [Bowyer 2008; Halla, Wagner and Zweimüller 2017; Lubbers, Scheepers and Billiet 2000; Scheepers, Gijsberts and Coenders 2002].

On the other hand, a line of research that integrates group threat theory and the competing intergroup contact theory suggests that the relationship between the size of a minority and support for the far right can be non-linear. Social interaction between the majority and the minority may lead to the elimination of prejudice in situations where the increasing size of a minority provides an opportunity for communication between both groups [Jolly and DiGiusto 2014; Pettigrew 1998]. Contact with a small minority increases tensions between groups, while contact with a large minority activates the mechanisms theorised by the intergroup contact theory, causing tension to decrease [Appadurai 2006]. Rink, Phalet and Swyngedou [2009] studied Belgian elections between 1991 and 1999 and found that the proportion of immigrants in a municipality had a positive effect on the likelihood of voters voting for Vlaams Blok. The positive effect of the size of the outgroup had a steep initial increase. However, it levelled with the growing number of immigrants.

Unfavourable economic conditions are another factor suspected of boosting far-right support. Rising unemployment and decreasing living standards may lead to blaming the minority and may also intensify the competition over scarce resources [Quillian 1995]. Better-off social strata are reluctant to pay taxes, which are redistributed as welfare for the minority groups. Less well-off groups believe that welfare should be reserved for natives [Kitschelt and McGann 1997: 22]. As Cochrane and Nevitte [2012] claim, when citizens choose their positions on the overall impact of immigration, economic conditions may be the crucial factor: while poor economic conditions increase the appeal of the anti-immigrant rheto- 
ric of far-right parties, good economic conditions predispose the voters to reject such stances. So, if far-right parties are successful in linking, for example, immigration and unemployment, this connection is more likely to turn people against immigrants in a period of high unemployment. Therefore, population segments facing economic hardship may be attracted to these parties not only, or primarily, because of their anti-immigration positions, but also as a sign of opposition to those who, in their view, are responsible for these bad conditions [Van Der Brug and Fennema 2003].

However, conclusions about economic factors influencing far-right support are not always confirmed [Bloom 2013; Amengay and Stockemer 2018]. Ivarsflaten [2005] notes that the far right may be divided with regard to economic interests, and Oesch [2008] shows that economic motives do not act as a significant factor in the decision to vote for the far right. In several cross-national studies, Golder [2003] finds that unemployment has a positive influence on far-right support only in the case of high immigration levels.

Even though Slovak far-right parties are anti-immigrant in their stances, because of the small numbers of immigrants in Slovakia the main targets of their prejudice have traditionally been the minorities living there. The Hungarian minority constitutes around $10 \%$ of the population in Slovakia, and it has been able to mobilise politically since the beginning of the existence of the Slovak Republic. This results in the permanent presence of some Hungarian minority parties in parliament (and in some cases government). ${ }^{1}$ The Roma minority makes up around $6.5 \%$ of the Slovak population [Matlovičová et al. 2012].

In the past, both of these minorities were targets, when the most prominent extreme-right party at the time - the Slovak National Party (SNS) — based a major part of its ideology on nationalism and xenophobia. However, after a change of leadership in 2012, the SNS moved closer to the centre of the political spectrum and this shift was confirmed after the 2016 election, when the Slovak National Party became a partner of MOST-HÍD, a Hungarian-minority party, in a coalition government led by the social-democratic SMER. Because the leading nationalist party had made compromises and become more moderate, the L'SNS took on the role as the real representative of the extreme right in Slovakia.

The People's Party-Our Slovakia is the latest newcomer in the 'club' of extreme-right political parties that have become relevant in Central Europe. ${ }^{2}$ Its direct predecessor-Slovak Togetherness (Slovenská pospolitost'-SP)—was founded around the current leader of the L'SNS Marian Kotleba and other former members of the Slovak neo-Nazi subculture in 2005. The SP party was dissolved

\footnotetext{
1 The 2020 elections are the first exception to this rule as no Hungarian minority party received enough support to pass the $5 \%$ threshold to enter the Slovak parliament.

${ }^{2}$ It should be noted that there is an ongoing academic debate about terminology and ideological classification of the far-right party family focusing on the question to what extent these parties are either radical or extreme in their ideology. According to the standard
} 
by the Slovak Supreme Court a year later. The court argued that its activities and anti-democratic electoral manifesto were in conflict with the Slovak constitution. After that, Kotleba, together with other members of the SP, founded the L'SNS with a modified manifesto, thanks to which they were gradually able to convince a part of the public that they were a real political actor and a legitimate alternative [Kluknavská and Smolík 2016]. Even though members of the L'SNS stopped marching in the streets with torches dressed in uniforms similar to those of the totalitarian Slovak state that was a puppet of the Nazis (1939-1945) as they had during the existence of the SP, parts of their manifesto remained similar. The ideology of the L'SNS includes all three core features of the far-right parties conceptualised by Mudde [2007]: authoritarianism - the L'SNS believes in a hierarchically ordered society, with corporatist features, its members regularly celebrating anniversaries connected to the totalitarian Slovak state; nativism-the L'SNS holds strong xenophobic and nationalistic views and is an anti-immigrant, anti-EU, anti-NATO, and, most of all, anti-minority party, and in this the L'SNS focuses especially on Roma and on the Hungarian minority; populism-Mudde [2004: 562] defines populism as 'an ideology that considers society to be ultimately separated into two homogeneous and antagonistic groups, the pure people versus the corrupt elite' and much like in the case of other European far right parties [Taggart 2000: 73], it is one of the central features of the L'SNS. The party promotes an anti-establishment and anti-elitist discourse and blames 'standard politicians' for corruption, fraud, embezzlement, and indifference to the needs of the 'common people'. One of the party slogans from the last electoral campaign can be loosely translated as 'We will deal with the thieves wearing ties as well as the parasites in the settlements!' [L'SNS 2016].

Even though the L'SNS is a parliamentary party that competed in a democratic election, based on the party's ideology and history and in line with previous studies of the Slovak far-right scene, we identify the party as extreme [e.g. Kluknavská and Smolík 2016]. The party not only shares former members and the ideology of the dissolved extreme-right Slovak Togetherness party, but also some of its MPs have faced prosecution for defamation of the nation, race, or beliefs.

Despite insufficient research on the L'SNS, those studies that exist suggest that its past support can be related to the presence of the Slovak Roma minority in the role of an alien outgroup and scapegoat. In their anti-Roma discourse, members of the L'SNS focus on two main aspects-crime (threat) and the welfare system (competition over resources). Roma are believed to be the perpetrators of criminal activities and the L'SNS blames the mainstream politicians for their in-

distinction, radical parties call for a massive reform of the system, but they do not necessarily call for the elimination of democracy. On the other hand, extreme parties are directly antagonistic to democracy. However, the dividing line between these two can be difficult to recognise, as far right parties may conceal their extremism to avoid legal action against them [Mudde 2007]. This is also the case of the L'SNS. 
ability to protect people from 'Gypsy extremism'. As one of their electoral goals, the L'SNS promised to 'deal with the parasites in the settlements' and to 'protect people from increasing Gypsy terror' [L'SNS 2016]. Also, the party manifesto describes the Roma as 'lazy Gypsies' abusing the social system, with the goal of removing 'the preferential treatment of (not only) Gypsy scroungers over decent people' [L'SNS 2016; Kluknavská and Smolík 2016]. Research shows that the party's success in the 2012 parliamentary elections was linked to the presence and size of the local Roma minority [Mikuš and Gurňák 2012]. This outcome is supported by Spáč and Voda [2014], who claim that the presence of the Roma is of vital importance to the party's results. L'SNS scores increase as the share of Roma in a municipality grows. Different types of Roma communities may also be a factor, so that areas with segregated Roma settlements create even more favourable conditions for extreme-right success. Spáč and Voda support these conclusions in their analysis of the party leader's success in the 2013 regional election, finding that: (a) a rising share of Roma in a municipality increased support for Kotleba and (b) areas with Roma neighbourhoods on the periphery and in segregated settlements generated more votes for Kotleba than areas with an unsegregated Roma population [Spáč and Voda 2015].

Based on the expectations of the group threat theory and the research presented above, our first hypothesis (H1) is: An individual's likelihood of voting for the L'SNS rises with the increasing share of the Roma minority in a municipality.

\section{Socio-demographic explanations for far-right support}

Apart from the contextual variables mentioned above, certain individual characteristics are also related to far-right support. Far-right parties are more likely to be supported by men [Fontana, Sidler and Hardmeier 2006]. Age is also considered to be an important predictor. For example, Lucassen and Lubbers [2012] find a linear negative relationship between age and voting for far-right parties. On the other hand, Arzheimer and Carter [2006] suggest that not only younger voters but also pensioners are more likely to vote for the far right, the reason being that younger and older people depend more on welfare than other age groups and are therefore more likely to view immigrants as competitors over resources. Studies suggest that those who are in direct competition with minority groups are more likely to develop prejudice against them and to support radical parties. This includes groups like the unemployed [Lucassen and Lubbers 2012], low-status workers and the underprivileged [Han 2016; Ivarsflaten 2005]. On the other hand, lower support for these political forces is linked to more educated voters [Rink, Phalet and Swyngedouw 2009].

Current analyses of the Slovak case mostly support these results. Support for the L'SNS in the 2012 parliamentary elections was stronger in areas with higher unemployment and a high share of people with low education and in areas with 
lower religiosity [Spáč and Voda 2014]. In the 2013 regional elections, a stronger preference for Kotleba was linked to male voters [Mikuš, Gurňák and Máriássyová 2016]. Moreover, as Gregor [2015] shows, in those elections, the L'SNS leader, Kotleba, was able to attract and mobilise a large group of people who consistently do not participate in elections. This finding is well in line with previous analyses on the connection between far-right support and political passivity [Schatz, Staub and Lavine 1999].

Based on these findings, our second hypothesis on individual inclinations to far-right support (H2) is: Young (H2a), male (H2b), lower-educated (H2c), bluecollar workers (H2d), the unemployed (H2e), and non-voters (H2f) are more likely to vote for the L'SNS.

\section{Data and methods}

Our analysis is based on exit-poll data. The data are unique because of the extralarge sample size and the fact that this was the first poll that demonstrated a considerable level of support for the L'SNS. The poll was conducted by a Slovakbased opinion poll agency (FOCUS) for the major Slovak private television channel Markíza during the election day. The exit-poll data include socio-demographic information on voters as well as information about their current vote and their

Table 1. Share of votes for political parties in the 2016 elections and the exit-poll estimate $(\%)$

\begin{tabular}{lccc}
\hline Political party & Official results & $\begin{array}{c}\text { Exit poll - result } \\
\text { estimate }\end{array}$ & Difference \\
\hline SMER - SD & 28.28 & 27.3 & 0.98 \\
SaS & 12.10 & 13.3 & -1.20 \\
OL'aNO - NOVA & 11.02 & 11.2 & -0.18 \\
SNS & 8.64 & 8.0 & 0.64 \\
L'SNS & 8.04 & 6.8 & 1.24 \\
MOST - HÍD & 6.50 & 7.3 & -0.80 \\
SME RODINA & 6.62 & 5.9 & 0.72 \\
SIEŤ & 5.60 & 6.7 & -1.10 \\
KDH & 4.94 & 5.0 & -0.06 \\
SMK & 4.04 & 3.6 & 0.44 \\
\hline
\end{tabular}

Note: The exit-poll electoral results estimation uses weighted exit-poll data. Our analysis uses unweighted exit-poll data.

Source: Exit poll 2016, FOCUS and the Slovak Statistical Office. 
vote in the previous elections. The exit-poll took place in 161 municipalities across Slovakia collecting answers from 20128 voters. This election-day poll estimated the final results quite accurately. The difference between the real and the polled results can be seen in Table 1 .

The empirical strategy of our study is based on analysing the connection between extreme-right support and both individual- and municipality-level variables. To respect the structure of our data, we employ hierarchical logistic regression in our analysis.

Our dependent variable in the analyses is whether the voter cast a vote for the L'SNS. Our individual-level independent variables are gender, age, education, unemployment, type of work, participation in the 2012 parliamentary elections, and ethnicity. While information on ethnicity is provided by the exit poll, the interviewee could only choose between Slovak, Hungarian, or 'other'. The very small share of voters with 'other' ethnicity in the dataset $(1.1 \%)$ suggests that not all Roma voters chose to identify as 'other'. The under-identification of Roma is also observed in the Slovak population and housing census, where a relevant share of Roma citizens reported their ethnicity as Slovak, Hungarian, or Ruthenian rather than Roma [Matlovičová et al. 2012]. If the electoral participation of the Roma is high, this could potentially conceal the connection between a vote for the extreme right and Roma presence in a municipality. However, we believe this is not the case. There is a strong negative correlation $(p=-0.55)$ between the share of Roma and electoral participation in a municipality. Also, the non-participation of Roma can be demonstrated directly in the rare cases when electoral districts match ethnic boundaries. Such is the case of the urban ghetto Lunik IX, which is a segregated Roma settlement in Košice. The two districts at Lunik IX had 6.0\% and $7.6 \%$ voter turnout in the 2016 parliamentary elections.

Individual variables are complemented by the contextual variables characterising the municipalities in which the exit poll was conducted. Information about the main independent contextual variable- the size of the Roma minority in the municipalities-is from the Atlas of Roma communities [Mušinka et al. 2014]. Fieldwork conducted for the Atlas in all the municipalities of Slovakia established the number of Roma citizens living in a municipality and the type of settlement (including information on whether it is segregated or not). The Roma minority is present in 91 of the 161 municipalities that were part of the exit poll. There are 36 municipalities with a share of Roma above $10 \%$ and seven with a Roma majority. A segregated Roma settlement was present in 18 municipalities.

Besides adding information on Roma presence as a municipality-level variable, we added the electoral results of the L'SNS in the municipality in the last parliamentary elections and unemployment in the municipality as control variables.

To control for the possible effects of the supposedly successful and important local campaign of the L'SNS, we also included a dummy on whether there was a campaign or any other activity by the LSNS in the municipality. While there is no research on the influence of campaigns on the electoral fortunes of 
Table 2. Descriptive statistics of the variables used in the models

\begin{tabular}{|c|c|c|c|c|c|}
\hline & Missing & Min. & Max. & Mean & Std. dev \\
\hline Male (dummy variable) & $2.5 \%$ & 0 & 1 & 0.488 & 0.500 \\
\hline Age (7 categories) & $1.8 \%$ & 1 & 7 & 3.993 & 1.655 \\
\hline Education (4 categories) & $2.9 \%$ & 1 & 4 & 3.030 & 0.850 \\
\hline $\begin{array}{l}\text { Hungarian ethnicity } \\
\text { (dummy variable) }\end{array}$ & $2.4 \%$ & 0 & 1 & 0.083 & 0.276 \\
\hline $\begin{array}{l}\text { Other ethnicity } \\
\text { (dummy variable) }\end{array}$ & $2.4 \%$ & 0 & 1 & 0.011 & 0.105 \\
\hline $\begin{array}{l}\text { Unemployed } \\
\text { (dummy variable) }\end{array}$ & $3.0 \%$ & 0 & 1 & 0.038 & 0.192 \\
\hline $\begin{array}{l}\text { Non-voter (dummy } \\
\text { variable) }\end{array}$ & $0.0 \%$ & 0 & 1 & 0.096 & 0.295 \\
\hline $\begin{array}{l}\text { Manual job } \\
\text { (dummy variable) }\end{array}$ & $3.0 \%$ & 0 & 1 & 0.191 & 0.393 \\
\hline $\begin{array}{l}\text { Roma present } \\
\text { (dummy variable) }\end{array}$ & $0.0 \%$ & 0 & 1 & 0.694 & 0.461 \\
\hline Roma share (\%) & $0.0 \%$ & 0 & 79.2 & 5.469 & 10.187 \\
\hline $\begin{array}{l}\text { Unemployment } \\
\text { level }(\%)\end{array}$ & $0.0 \%$ & 2.7 & 73.24 & 14.868 & 7.834 \\
\hline $\begin{array}{l}\text { L'SNS meeting } \\
\text { (dummy variable) }\end{array}$ & $0.0 \%$ & 0 & 1 & 0.275 & 0.447 \\
\hline $\begin{array}{l}\text { L'SNS other activity (dum- } \\
\text { my variable) }\end{array}$ & $0.0 \%$ & 0 & 1 & 0.279 & 0.448 \\
\hline $\begin{array}{l}\text { L'SNS election result } \\
\text { in } 2012(\%)\end{array}$ & $0.0 \%$ & 0 & 5.26 & 1.406 & 0.984 \\
\hline $\begin{array}{l}\text { Segregated settlement } \\
\text { present (dummy variable) }\end{array}$ & $0.0 \%$ & 0 & 1 & 0.183 & 0.387 \\
\hline
\end{tabular}

Source: Exit poll 2016, FOCUS and the Slovak Statistical Office.

the extreme right in Slovakia, after the success of the L'SNS in the parliamentary elections, the Slovak media singled out the party's activities on the local level as one of the sources of its electoral good fortune. There is also limited research on the effects of campaigns of similar parties in other countries. However, some insight is provided by Cutts and Goodwin [2014] for the case of Britain. Their findings show that even though the British National Party (BNP) polled strongest in working-class manufacturing areas, its support was significantly higher in areas where it had run intensive local campaigns, recruited larger numbers of members, and achieved local electoral success. Also, voters contacted by the BNP 
campaign were significantly more likely to vote for the party. On the other hand, electoral gains were not enhanced in areas where the English Defence League social movement had previously demonstrated.

We gathered information about L'SNS activities from its official website and Facebook profile. Our analysis considers all actions organised by the party since 2014. We distinguish election-related activities (campaign rallies) and other events (i.e. marches, protests, and memorial events). The L'SNS campaigned in 19 out of 161 exit-poll municipalities, and other events organised by the party were identified in 13 municipalities.

\section{Results}

Our approach relies on hierarchical logistic regression, which allows us to explain the vote for the extreme right on the basis of individual characteristics and municipality-level contextual variables. After presenting the baseline without predictors, we first add individual-level variables (Models 1 and 2 in Table 3). Later, in Models 3 and 4 (Table 3) we include alternative measures of Roma presence in a municipality. Information on model fit is provided by the log-likelihood values and the AIC information criteria. With regard to municipality-level variables, our modelling strategy was to first include only the municipality-level variables on Roma presence (Models 3 and 4) to avoid potential bias resulting from the fact that they could be connected to other municipality-level variables (e.g. unemployment level or L'SNS activity). Moreover, we include the variable on Roma presence in our models in two alternative ways: first, as a binary variablewhether the Roma minority lives in a municipality (Model 3 in Table 3 and Models 5 and 6 in Table 4); second, as the relative size of the local Roma minority in a municipality (Model 4 in Table 3 and Models 7 and 8 in Table 4). As there proved to be no support for the connection between Roma presence and a vote for the LSNS in Models 3, 4, 5, and 7, we decided also to check for potential interactions between individual-level predictors and Roma presence in a municipality. These are included in Models 6 and 8 in Table 4. This also allows us to test the competition for resources assumption, according to which unemployment should matter only if there is a higher share of Roma in the municipality [see, e.g., Golder 2003].

Regarding the connection between a vote for the extreme right and the presence of Roma in a municipality, the results in Tables 3 and 4 do not confirm our first hypothesis in either of the models. The size, or even the mere presence, of the Roma minority in a municipality did not influence an individual's decision to vote for the L'SNS. We therefore cannot confirm the hypothesis that the presence of Roma in a municipality increases an individual's likelihood of voting for the extreme right. To verify this conclusion, we also tested the prediction of Spáč and Voda [2014] that support for the L'SNS is higher in municipalities where a segregated Roma settlement is present by including a dummy variable on segregated 
settlements in Models 5 to 8 in Table 4. Yet, not even the presence of a segregated Roma settlement was a statistically significant predictor of a vote for the L'SNS.

The interaction effects of Roma presence and individual-level variables are reported in Table 5. They are reported as significant for voters in the age categories 22-29, 50-59, and 60-69. Figure 1 provides a visualisation of the marginal effects of our model for these age categories. As can be seen, in the 22-29 age category, when there are Roma present in a municipality, voters are less likely to cast a vote for the L'SNS. On the other hand, in the two higher age categories, which are generally the least inclined to vote for the extreme right, Roma presence seems to increase the likelihood of support for the L'SNS. Another significant interaction is between Roma presence and university education. University-educated voters, who are generally the least supportive of the L'SNS, seem to show stronger support if Roma are present in a municipality. However, no interactions are significant if the share of Roma is included in the model, although the interaction between the share of Roma and being unemployed comes close to the 0.05 threshold.

In general, these models provide little support for the idea that a vote for the extreme right in the 2016 Slovak parliamentary elections can be explained by the experience of living in proximity to the Roma minority (H1). What is more, we were also unable to discover a connection between Roma presence and a vote for the extreme right through analyses of the sub-samples of municipalities with a share of Roma lower than 10\% (125 municipalities), 5\% (103 municipalities), and $2 \%$ (85 municipalities). If there seems to be a positive connection between Roma presence and a vote for the L'SNS, it is in the groups least likely to cast a vote for the L'SNS-older and university-educated voters.

Based on the results presented in Tables 3 and 4, we conclude that age and gender are significant predictors of voting for the extreme right. Young voters and males were more likely to support the L'SNS than older voters and females (H2a, H2b). Also, voters with lower education, manual workers, and people who did not participate in previous parliamentary elections were more likely to cast a vote for the extreme right $(\mathrm{H} 2 \mathrm{c}, \mathrm{H} 2 \mathrm{~d}, \mathrm{H} 2 \mathrm{f})$. On the other hand, this likelihood decreases if the voter was of Hungarian ethnicity. We can thus partially confirm our second hypothesis, that young, male, working-class voters are more likely to vote for the extreme right. However, we do not find a relationship between support for the L'SNS and unemployment (H2e). Even so, the interaction term of unemployment and the share of Roma in a municipality in Model 8 (Table 5) is almost significant $(p=0.053)$, suggesting a relationship opposite to the expectation indicated by the literature [Golder 2003] — the higher the share of Roma in a municipality, the less likely the unemployed were to vote for the L'SNS.

The connection between municipality-level unemployment and a vote for the L'SNS was not confirmed either in the analysis of the whole sample presented in Table 4 or in analyses of sub-samples of the exit-poll data, which included only municipalities with a lower share of Roma. 


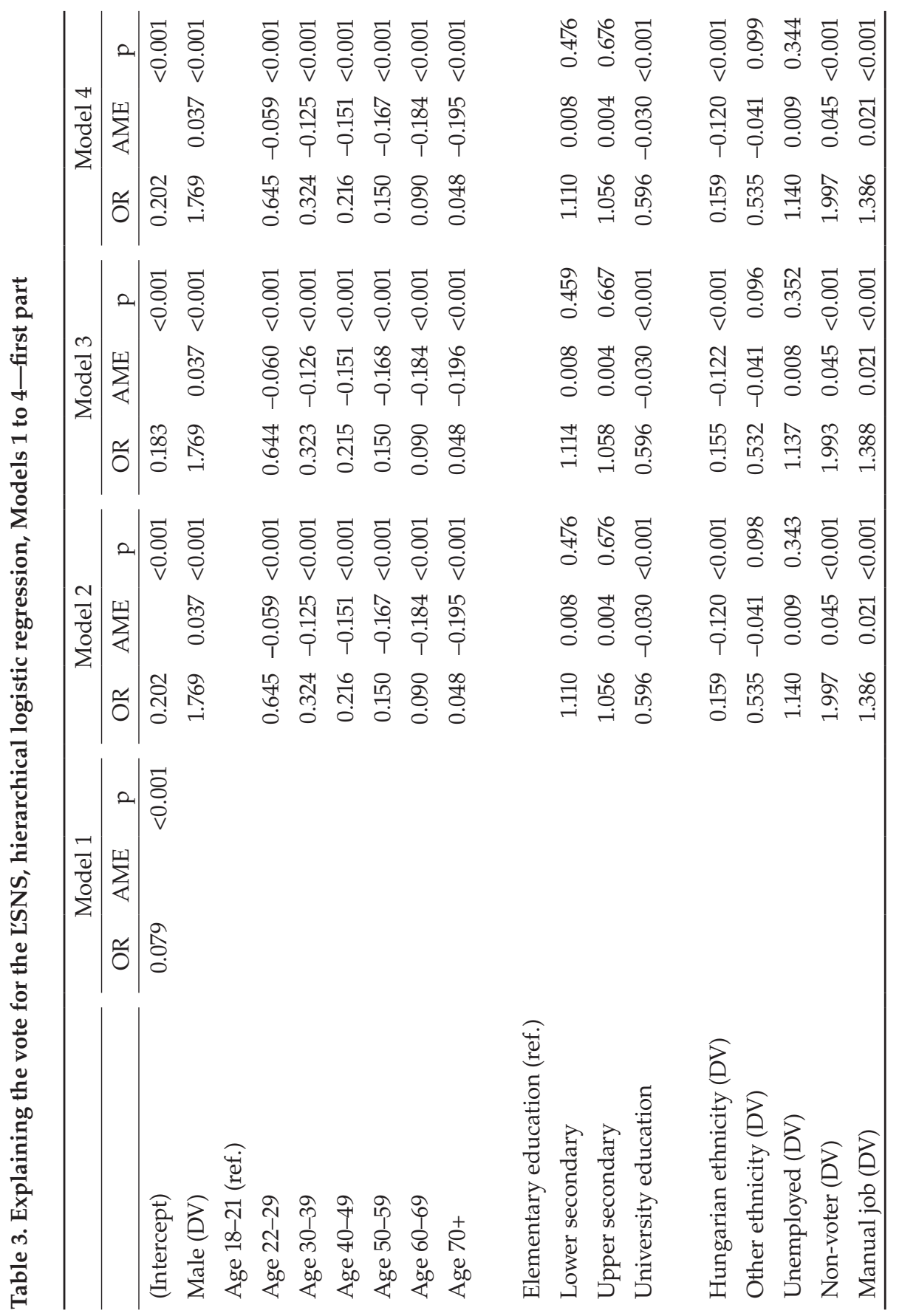




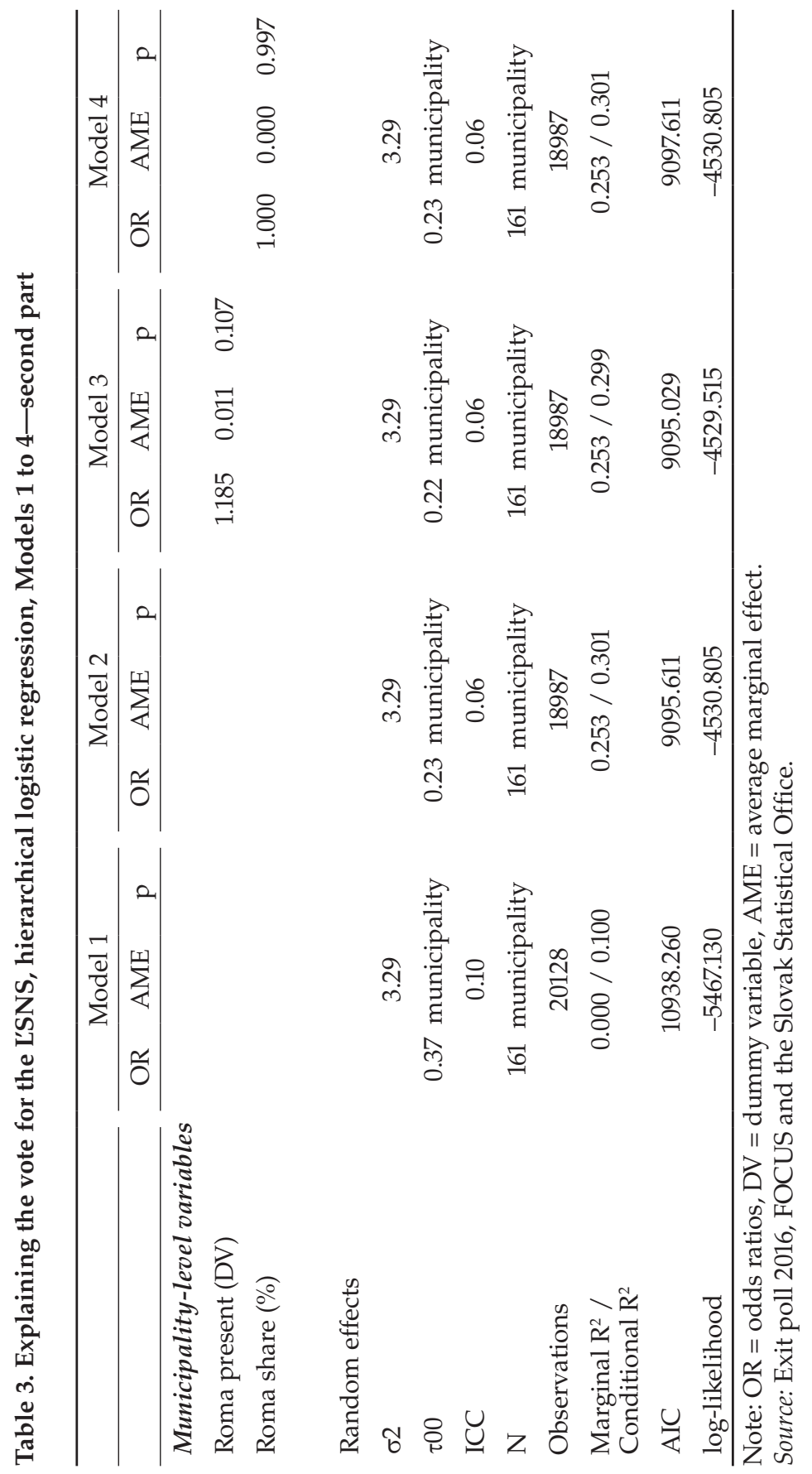




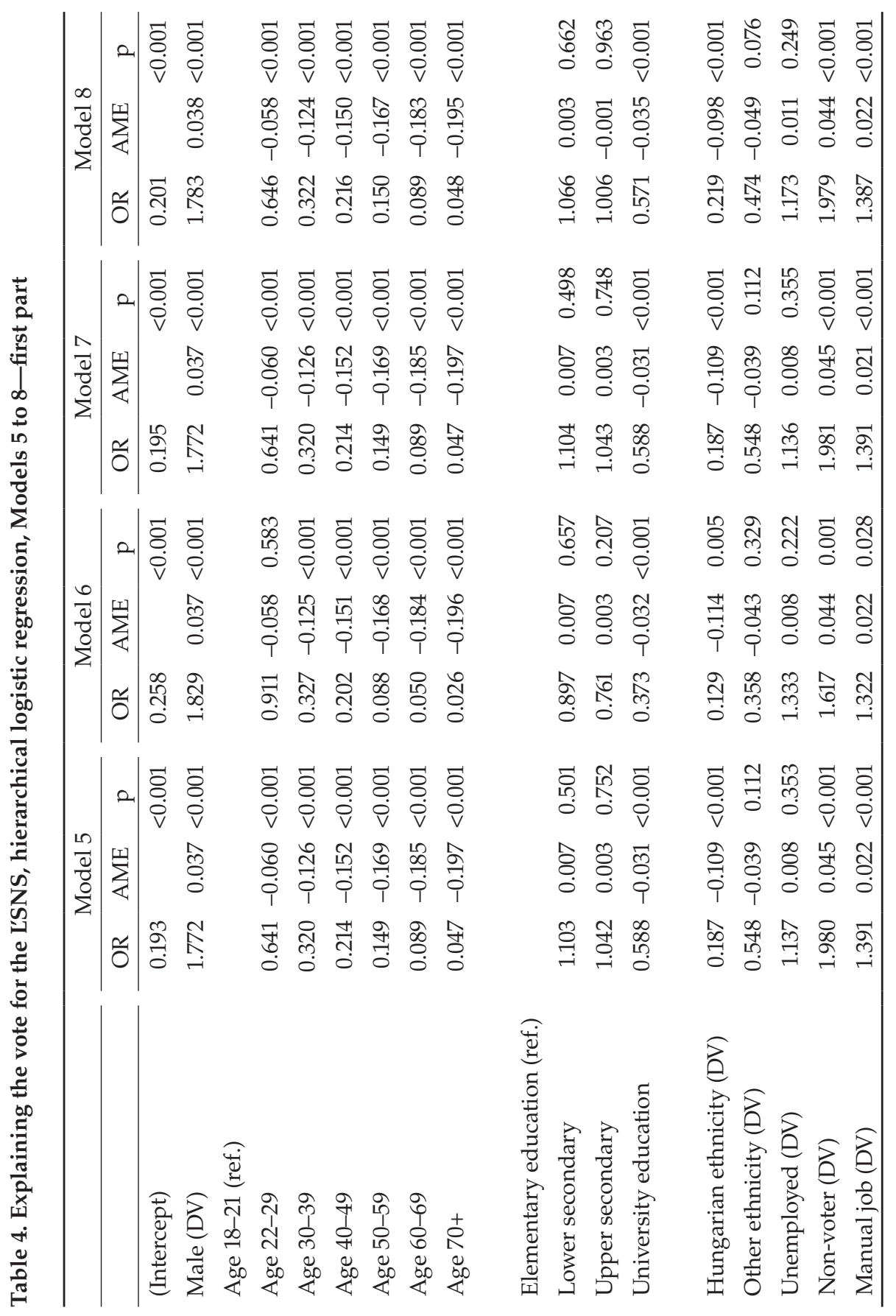




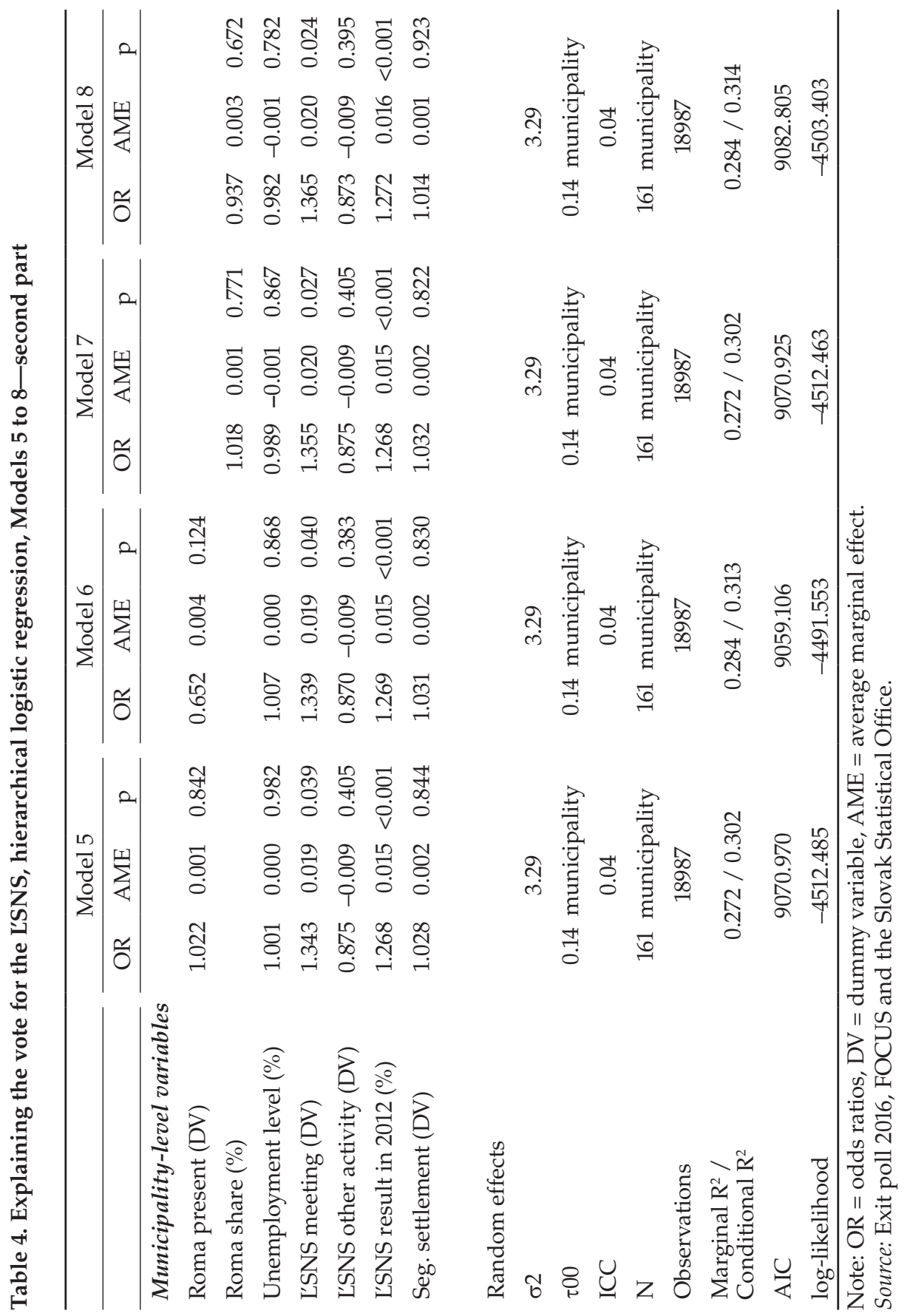


Sociologický časopis/Czech Sociological Review, 2020, Vol. 56, No. 3

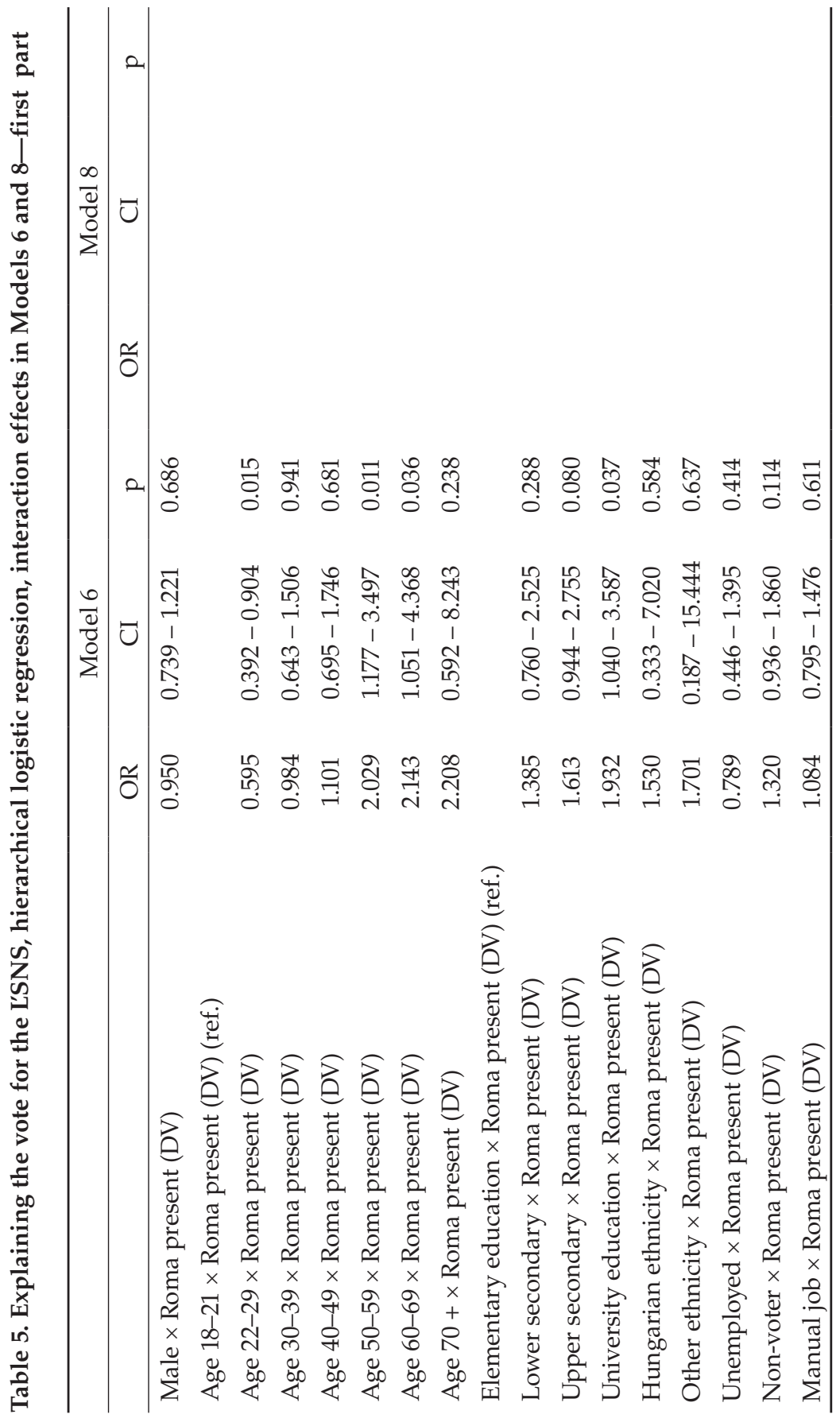




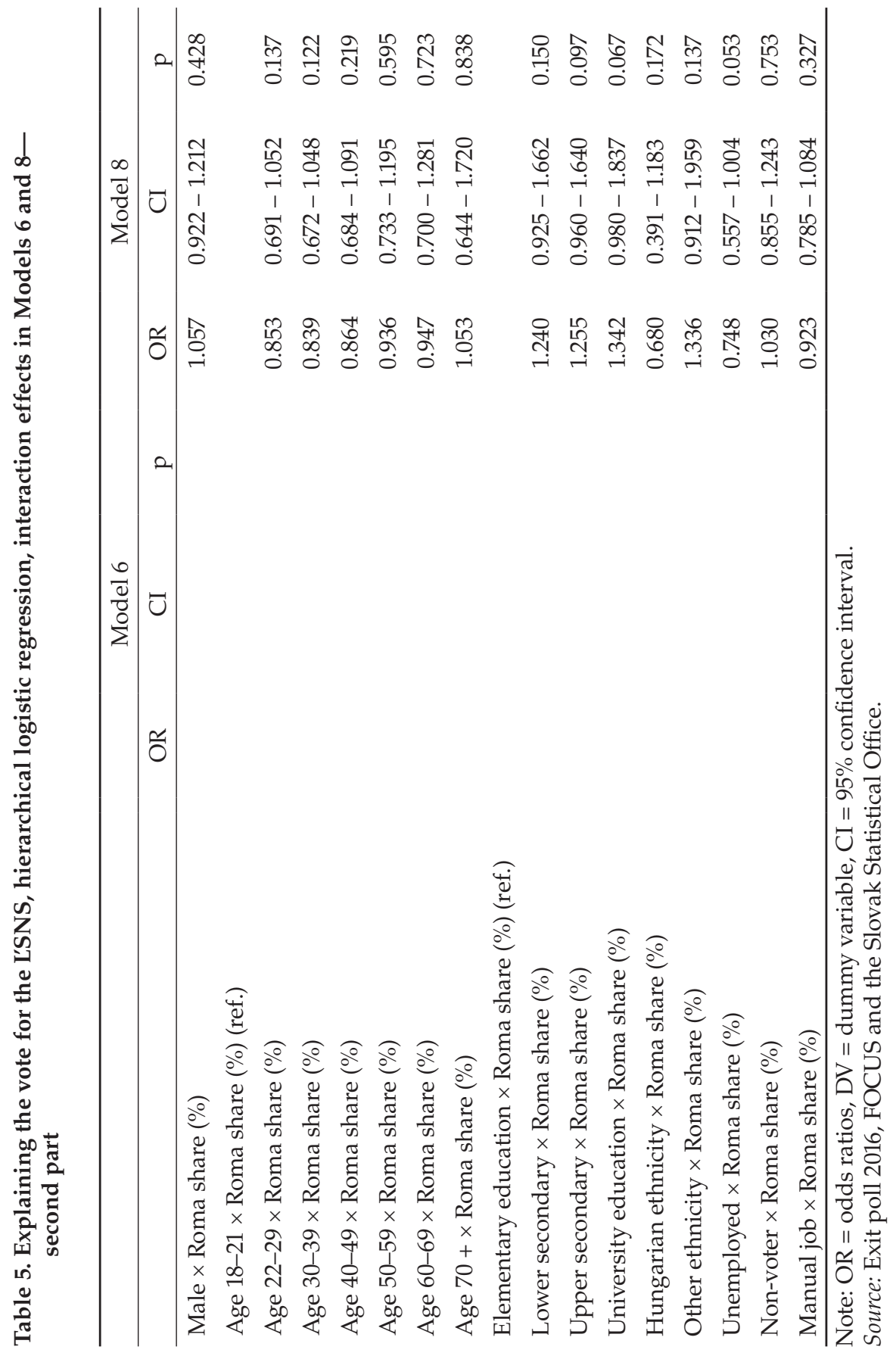


Figure 1. Explaining the vote for the L'SNS, marginal effects for Models 6 and 8

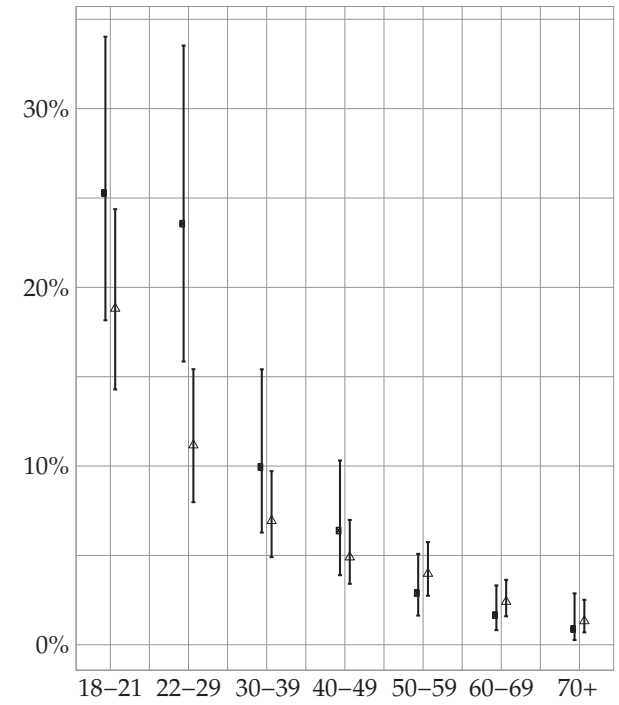

Roma present

No $\triangle$ Yes

(a) vote for the L'SNS by age groups and the presence of Roma (DV)

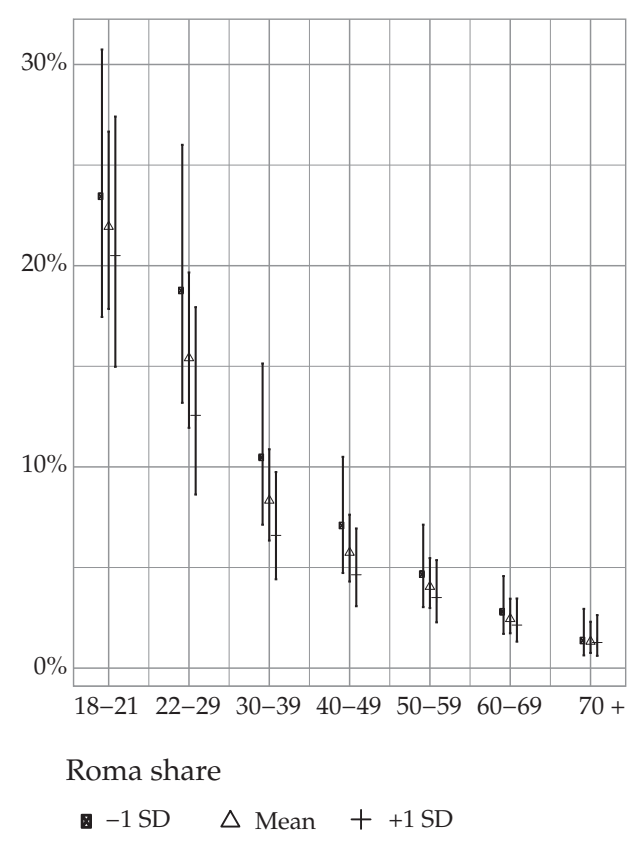

(b) vote for the L'SNS by age groups and the share of Roma in a municipality

One of the two variables that were intended as measures of the L'SNS's involvement at the local level is connected to a vote for the far right. Our results in Table 4 show that a campaign rally has some effect on the vote $(p<0.05)$, but no relationship is found between the vote and other activities, such as the protests or marches of the L'SNS. As can be seen in Table 4, another significant municipalitylevel predictor of a vote for the L'SNS is the party's 2012 electoral result. This suggests that, controlling for all other variables in the model, the party was stronger in places where it had already been successful in 2012.

It should be noted, however, that with over 20000 responses, the statistical power of our individual-level variables is notably higher than the analysis of municipality-level variables, where we analysed 161 municipalities. Moreover, two municipality-level variables - unemployment and the share of Roma-are highly correlated. As a robustness check for potential multicollinearity, we therefore excluded municipality-level unemployment from Models 5 to 8. This omission did not change the presented results. ${ }^{3}$

${ }^{3}$ These models are available from the authors upon request. 


\section{Conclusion}

Contrary to several previous studies, our analysis was unable to find a consistent connection between the presence of the Roma minority and electoral support for the extreme right. When controlling for individual-level socio-demographic variables, majority voters living in municipalities with a Roma presence were not more likely to vote for the extreme right in the 2016 Slovak parliamentary elections. Moreover, the connection was not found even in the more extreme case of municipalities with the presence of segregated Roma settlements. The analysis of models with interactions between Roma presence and the age and education of the voters suggests that Roma presence might be connected to higher support for the extreme right in the groups that are generally the least likely to support the LSNS (the university-educated and older respondents).

This is an important finding about the connection between extreme-right anti-minority rhetoric and its electoral success and raises the wider question about changes in the electoral base of the more successful extreme-right parties. Still, our data do not permit us to claim that anti-minority sentiment did not play a role. It is possible that some voters might have been motivated to vote for the LSNS even if they did not experience direct contact with the minority but still felt threatened, as is sometimes the case [Branton et al. 2011]. Our hypothesis is that, while the electoral success of the extreme right remains rather small and it currently exists as a fringe political actor, anti-minority sentiment is one of the key predictors of its success. However, if the extreme-right party can attract a substantially higher share of votes, different factors come into play as well.

The main ingredient of the L'SNS's 2016 electoral success was possibly not its anti-Roma rhetoric. Rather, the extreme right was successful in posing as the only viable alternative to the generally mistrusted political leaders. This is demonstrated, for instance, by the fact that the party was able to mobilise a considerable share of usually passive non-voters. While we are aware that exit-poll data cannot justify the claim that the success of the L'SNS in 2016 was due to the protest vote, we believe that this hypothesis is worth testing in the future research of electoral gains of the extreme right. A protest vote, or an expression of political distrust, is sometimes mentioned as a reason for the emergence of the far right in various countries [Rooduijn 2017]. The case of the L'SNS and its results can be viewed as similar to the success of the True Finns Party in the 2011 Finnish parliamentary elections, Golden Dawn in Greece in the 2014 European elections, or-from the countries neighbouring Slovakia—to the successful Hungarian extreme-right party Jobbik. The socio-structural macro-level characteristics (such as unemployment or the number of immigrants), which have typically explained the popularity of the far right elsewhere, did not fit for the result of the True Finns. Their electoral gains were more of an expression of political protest throughout Finland [Westinen 2014]. Even with its authoritarian neo-Nazi stance, Golden Dawnideologically much closer to the L'SNS than the True Finns-was able to capitalise on the de-legitimation of Greek political institutions and to present itself as a 
socially legitimate anti-system alternative [Ellinas 2015]. Jobbik, as well, was able to take advantage of the Hungarian political situation and the crisis of traditional democratic parties [Mareš and Havlík 2016].

Strong anti-system and anti-corruption stances were presented as a central feature of the L'SNS in its campaign, and more than $20 \%$ of the party's voters indicated the fight against corruption as the main reason for choosing the L'SNS. With corruption having been singled out as one of the biggest problems in Slovakia by citizens for many years in various surveys [Džambazovič 2015], it seems that, much like Golden Dawn, the L'SNS was able to overshadow its authoritarian ideology and persuade a part of the electorate that the party is the answer to some of the most gruelling problems in Slovak society.

Our results differ from previous analyses of the electoral gains of the Slovak extreme right. These were, however, not analyses of major electoral successes. The L'SNS was a fringe party in the previous parliamentary elections, and its support could clearly be connected to an outgroup presence. In 2016, however, the L'SNS was not only able to hold on to its previous electorate, but at the same time it succeeded in attracting a large share of non-voters and ex-voters of other political parties. We are aware that further empirical evidence for the hypothesis that the extreme right's electoral support in Slovakia has changed from being driven by anti-minority sentiment (connected to the presence of an out group) to a protest vote is needed. For now, however, the explanation of a vote for the extreme right as a desperate move of the majority frightened by experiencing a Roma presence does not seem to be the most likely.

MiLOSLAv BAHNa is a senior researcher at the Institute for Sociology of the Slovak Academy of Sciences. He is a representative of the Institute in the International Social Survey Programme (ISSP). His research interests include the sociology of migration and quantitative methodology. His research was published in the International Migration Review, Population, Space and Place, Studies in Higher Education, and other journals.

JOZEF ZAGRAPAN is a postdoctoral associate at the Institute for Sociology of the Slovak Academy of Sciences. His research focuses mainly on Slovakia in cross-national comparative research, experimental methods, political communication, and electoral behaviour. His work has been published in Government Information Quarterly, European Journal of Communication, and Sociológia-Slovak Sociological Review. 


\section{References}

Amengay, A. and D. Stockemer. 2018. 'The Radical Right in Western Europe: A MetaAnalysis of Structural Factors.' Political Studies Review 17 (1): 30-40, https://doi.org/10.1177/1478929918777975.

Appadurai, A. 2006. Fear of Small Numbers: An Essay on the Geography of Anger. Durham, NC: Duke University Press, https://doi.org/10.1215/9780822387541.

Arzheimer, K. and E. Carter. 2006. ‘Political Opportunity Structures and Right-Wing Extremist Party Success.' European Journal of Political Research 45 (3): 419-443, https://doi.org/10.1111/j.1475-6765.2006.00304.x.

Blalock, H. 1967. Towards a Theory of Minority Group Relations. New York: John Wiley and Sons.

Bloom, S. 2013. 'Minority Group Size, Unemployment, and the Extreme Right Vote: The Crucial Case of Latvia.' Social Science Quarterly 94 (3): 795-810, https:// doi.org/10.1111/j.1540-6237.2012.00877.x.

Blumer, H. 1958. 'Race Prejudice as a Sense of Group Position.' Pacific Sociological Review 1: 3-7, https://doi.org/10.2307/1388607.

Bowyer, B. 2008. 'Local Context and Extreme Right Support in England: The British National Party in the 2002 and 2003 Local Elections.' Electoral Studies 27 (4): 611-620, https://doi.org/10.1016/j.electstud.2008.05.001.

Branton, R., E. C. Cassese, B. S. Jones and C. Westerland. 2011. 'All Along the Watchtower: Acculturation Fear, Anti-Latino Affect, and Immigration.' The Journal of Politics 73 (3): 664-679, https://doi.org/10.1017/S0022381611000375.

Cutts, D. and M. J. Goodwin. 2014. 'Getting Out the Right-Wing Extremist Vote: Extreme Right Party Support and Campaign Effects at a Recent British General Election.' European Political Science Review 6: 93-114, https://doi.org/10.1017/S1755773912000288.

Džambazovič, R. 2015. 'Názory verejnosti na korupciu: Je na Slovensku korupčná klíma?' (Public opinion on corruption: is there an environment of corruption in Slovakia?) Pp. 422-459 in Korupcia, edited by P. Šoltés and L. Vörös. Bratislava: Historický ústav SAV: Veda.

Ellinas, A. A. 2015. 'Neo-Nazism in an Established Democracy: The Persistence of Golden Dawn in Greece.' South European Society and Politics 20 (1): 1-20, https://doi.org/10.1080/13608746.2014.981379.

EVS. 2011. 'European Values Study 1981-2008, Longitudinal Data File'. GESIS Data Archive, Cologne, ZA4804 Data File Version 2.0.0.

Fontana, M.-C., A. Sidler and S. Hardmeier. 2006. 'The New Right Vote: An Analysis of the Gender Gap in the Vote Choice for the SVP.' Swiss Political Science Review 12 (4): 243-271, https://doi.org/10.1002/j.1662-6370.2006.tb00067.x.

Fontanella, L., P. Villano and M. Di Donato. 2015. 'Attitudes towards Roma People and Migrants: A Comparison through a Bayesian Multidimensional IRT Model.' Quality $\mathcal{E}$ Quantity 50 (2): 471-490, https://doi.org/10.1007/s11135-014-0158-9.

Golder, M. 2003. 'Explaining Variation in the Success of Extreme Right Parties in Western Europe.' Comparative Political Studies 36 (4): 432-466, https://doi.org/10.1177/0010414003251176.

Gregor, K. 2015. 'Who Are Kotleba's Voters? Voters' Transitions in the Banská Bystrica Region in 2009-2014.' Sociológia 47 (3): 235-252.

Han, K. J. 2016. 'Income Inequality and Voting for Radical Right-Wing Parties.' Electoral Studies 42: 54-64, https://doi.org/10.1016/j.electstud.2016.02.001.

Halla, M., A. Wagner and J. Zweimüller. 2017. 'Immigration and Voting for the Far Right.' Journal of the European Economic Association 000: 1-45, https://doi.org/10.1093/jeea/jvx003. 
Ivarsflaten, E. 2005. 'The Vulnerable Populist Right Parties: No Economic Realignment Fuelling Their Electoral Success.' European Journal of Political Research 44 (3): 465-492, https://doi.org/10.1111/j.1475-6765.2005.00235.x.

Jolly, S. K. and G. M. DiGiusto. 2014. 'Xenophobia and Immigrant Contact: French Public Attitudes Toward Immigration.' The Social Science Journal 51 (3): 464-473, https://doi.org/10.1016/j.soscij.2013.09.018.

Kitschelt, H. and A. McGann. 1997. The Radical Right in Western Europe. A Comparative Analysis. Ann Arbor, MI: University of Michigan Press, https://doi.org/10.3998/mpub.14501.

Kluknavská, A. and J. Smolík. 2016. 'We Hate Them All? Issue Adaptation of Extreme Right Parties in Slovakia 1993 and 2016.' Communist and Post-Communist Studies 49 (4): 335-344, https:// doi.org/10.1016/j.postcomstud.2016.09.002.

L'SNS. 2016. NAŠE SLOVENSKO—noviny politickej strany Mariana Kotlebu (OUR SLOVAKIA - newspaper of Marian's Kotleba political party) Manifesto. Retrieved 29 October 2019 http://www.naseslovensko.net/wp-content/uploads/2016/02/naseslovensko-februar-2016.pdf.

Lubbers, M., M. Gijsberts and P. Scheepers. 2002. 'Extreme Right-Wing Voting in Western Europe.' European Journal of Political Research 41 (3): 345-378, https://doi.org/10.1111/1475-6765.00015.

Lubbers, M., P. Scheepers, and J. Billiet. 2000. 'Multilevel Modelling of Vlaams Blok Voting: Individual and Contextual Characteristics of the Vlaams Blok Vote.' Acta Politica 35 (4): 363-398.

Lucassen, G. and M. Lubbers. 2012. ‘Who Fears What? Explaining Far-Right Wing Preference in Europe by Distinguishing Perceived Cultural and Economic Ethnic Threats.' Comparative Political Studies 45 (5): 547-574, https://doi.org/10.1177/0010414011427851.

Mareš, M. and V. Havlík. 2016. 'Jobbik's Successes. An Analysis of Its Success in the Comparative Context of the V4 Countries.' Communist and Post-communist Studies 49 (4): 323-333, https://doi.org/10.1016/j.postcomstud.2016.08.003.

Matlovičová, K., R. Matlovič, A. Mušinka and A. Židová. 2012. ‘The Roma Population in Slovakia. Basic Characteristics of the Roma Population with Emphasis on the Spatial Aspects of Its Differentiation.' Pp. 77-104 in Roma Population on the Peripheries of the Visegrad Countries. Spatial Trends and Social Challenges, edited by J. Penczes and Z. Radics. Debrecen: Didakt.

Mikuš, R. and D. Gurňák. 2012. 'Vývoj pozícií politického extrémizmu, radikalizmu a nacionalizmu v rôznych úrovniach volieb na Slovensku.' (Development of the position of political extremism, radicalism, and nationalism in different stages of the elections in Slovakia) Geografické informácie/Geographical Information 16 (2): 38-49, https://doi.org/10.17846/GI.2012.16.2.38-49.

Mikuš, R., D. Gurňák and A. Máriássyová. 2016. 'Analýza volebnej podpory Mariána Kotlebu ako reprezentanta krajnej pravice v krajských vol'bách 2013.' (An analysis of voter support for Marián Kotleba as the representative of the far-right in the regional elections of 2013) Sociológia 48 (1): 48-70.

Mudde, C. 2004. 'The Populist Zeitgeist.' Government and Opposition 39 (4): 541-463, https:// doi.org/10.1111/j.1477-7053.2004.00135.x.

Mudde, C. 2007. The Populist Radical Right in Europe. Cambridge: Cambridge University Press, https://doi.org/10.1017/CBO9780511492037.

Mušinka, A., D. Škobla, K. Matlovičová and J. Kling. 2014. Atlas rómskych komunít na Slovensku 2013. (Atlas of Roma communities in Slovakia 2013) Bratislava: UNDP.

Oesch, D. 2008. 'Explaining Workers' Support for Right-Wing Populist Parties in 
Western Europe: Evidence from Austria, Belgium, France, Norway, and Switzerland.' International Political Science Review 29 (3): 349-373, https://doi.org/10.1177/0192512107088390.

Pettigrew, T. F. 1998. 'Intergroup Contact Theory.' Annual Review of Psychology 49: 65-85, https://doi.org/10.1146/annurev.psych.49.1.65.

Quillian, L. 1995. 'Prejudice as a Response to Perceived Group Threat.' American Sociological Review 60: 586-611, https://doi.org/10.2307/2096296.

Rink, N., K. Phalet and M. Swyngedouw. 2009. 'The Effects of Immigrant Population Size, Unemployment, and Individual Characteristics on Voting for the Vlaams Blok in Flanders 1991-1999.' European Sociological Review 25 (4): 411-424, https://doi.org/10.1093/esr/jcn028.

Rooduijn, M. 2017. 'What Unites the Voter Bases of Populist Parties? Comparing the Electorates of 15 Populist Parties.' European Political Science Review 10 (3): 1-18, https://doi.org/10.1017/S1755773917000145.

Schatz, K T., E. Staub and H. Lavine. 1999. 'On the Varieties of National Attachment: Blind Versus Constructive Patriotism.' Political Psychology 20 (1): 151-174, https://doi.org/10.1111/0162-895X.00140.

Scheepers, P., M. Gijsberts and M. Coenders. 2002. 'Ethnic Exclusion in European Countries. Public Opposition to Civil Rights for Legal Migrants as a Response to Perceived Threat.' European Sociological Review 18: 17-34, https://doi.org/10.1093/esr/18.1.17.

Spáč, P. and P. Voda. 2014. 'Slovak Extreme Right and Its Support Based on Local Roma Incidence.' Paper presented at the ECPR General Conference, Glasgow, September 3-6.

Spáč, P. and P. Voda. 2015. 'Just a Roma Issue? The Support for Marian Kotleba in 2013 Regional Elections.' Pp. 88-100 in Mechanism of Voter Mobilisation of L'SNS and Marián Kotleba, edited by K. Gregor, J. Medzihorský, P. Spáč, M. Škop and P. Voda. Bratislava: Centre for European and North Atlantic Affairs.

Taggart, P. 2000. Populism. Buckingham: Open University Press.

Van der Brug, W., M. Fennema and J. Tillie. 2000. 'Anti-Immigrant Parties in Europe: Ideological or Protest Vote?' European Journal of Political Research 37 (1): 77-102, https://doi.org/10.1111/1475-6765.00505.

Westinen, J. 2014. 'True Finns: A Shock for Stability? Testing the Persistence of Electoral Geography in Volatile Elections.' Scandinavian Political Studies 37 (2): 123-148, https://doi.org/10.1111/1467-9477.12017. 